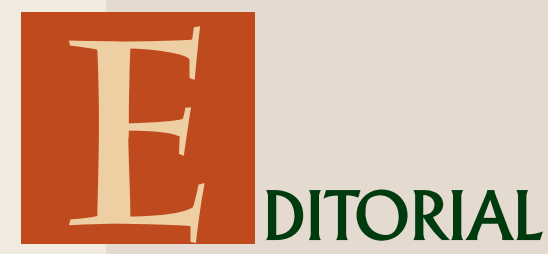

Jeanne Marie Machado de Freitas 1

\title{
Revistas científicas e a formação de pesquisadores
}

jeanne.marie@uol.com.br

2

CALIGRAMA, número 3, propõese como Revista Científica destinada a expor saberes que são o resultado do conjunto de ciências que constituem o campo das Ciências da Linguagem e também resultam, esses saberes, no avanco do conhecimento.
3 do pesquisador são tributárias do artigo $A$ Ciência e a Verdade na Formação do Analista Lacaniano, de Tânia Coelho dos Santos,

Coordenadora do Programa de PósGraduação em Teoria Psicanalítica, da Universidade Federal do Rio de Janeiro. $\mathrm{O}$ artigo será publicado na revista eletrônica Acheronta.
CALIGRAMA 2 , como todas as revistas científicas, desempenha várias funções, dentre as quais privilegia a função de contribuir para a formação de pesquisadores.

A publicação de artigos, entendida como uma exposição de conhecimento, resulta de um conjunto de atividades que reúne, por um lado, o estudar, o pensar e o elaborar e, por outro, a demonstração do modo pelo qual o trabalho se situa no campo dos saberes.

A exposição relaciona-se, assim, no primeiro momento, à aquisição de conhecimentos e, no segundo, atesta a pertença a esse ou àquele domínio do saber, o que implica o reconhecimento de uma herança e, em consequêencia, de um antes. $\mathrm{O}$ trabalho detém um certo usufruto sobre a herança, o que estabelece também uma dívida, de onde decorre uma condição: o ampliar e o desenvolver a potencialidade que a herança representa.

A espiral é uma figura que ilustra bem o movimento do ir e vir do trabalho à herança e da herança ao trabalho que se faz. A ética acompanha o movimento de tal modo que o esquecimento e o gasto indiscriminado da herança constituem violação das suas normas, ou seja, desrespeitam a própria instituição do campo científico.

A passagem por esse processo é árdua e dolorosa, pois nada mais é do que uma separação pela qual o pesquisador em formação se separa do saber que adquiriu e que pensa ter inventado e é reconduzido à dívida para com este ou aquele legado. Separação necessária que permite ao pesquisador, na recondução àqueles que o antecederam, diferenciar a questão que o move e capacitar-se para produzir a sua própria contribuição. $\mathrm{O}$ inédito, o não ainda dito, procede de forma única e absoluta desse movimento.

Assim, do pós-graduando candidato ao grau de mestre esperamos que, ao fim de um certo percurso, seja capaz de recensear bibliografias distinguindo as posições dos diferentes autores, independentemente, até certo ponto, de suas opiniões; do candidato ao grau de doutor esperamos que se reconheça numa determinada tradição, que possa se distinguir de outras e que tenha se capacitado a introduzir algo de seu para fazer avançar a pesquisa no campo que o atraiu $\mathbf{3}$. 
Claro está que o processo na sua inteireza requer, na outra ponta, alguém que, ao atravessar esse caminho da forma desejada, tenha se capacitado a formular a sua própria interrogação e a elaborar parâmetros consistentes para construir a sua contribuição. É neste ponto que se diferenciam o professor e o instrutor: aquele que impulsiona o movimento em espiral e o que insiste no círculo utilitário do fazer imediato.

CALIGRAMA, número 3, instala a editoria - ARQUIVO - também para repor componentes do legado. Inauguramo-la com o artigo Imagens pornográficas e imagens artísticas: esboço de uma teoria da substância semiótica da imagem, de R. Lindekens, da Universidade de Montreal, que se fundamenta na glossemática do dinamarquês Louis Hjelmslev para pensar a diferenciação indicada no título, que é sempre problemática.

A discussão muito atual entre ficção e realidade, retomada na relação com a estrutura narrativa, o que significa trazer R. Barthes para a cena, é trabalhada nos textos de Daisi Vogel, ao tratar do relato jornalístico e de Mayra M. Carvalho, preocupada com o jogo de futebol televisionado. Ainda na esteira dessa discussão, Aluízio R. Trinta, do lugar filosófico, volta-se para a telenovela, pensando-a na confluência estética de Romantismo e Realismo. A configuração do tempo nas narrativas literárias, Mrs. Dalloway e As Horas, no ensaio de Andiara Petterle, evoca questões nunca superadas.

Gislene Silva interessa-se pela produção do sentido no jornalismo e percorre vários estudos que tratam do tema destacando duas vertentes: a construção social da realidade e a narrativa jornalística.

Adalberto Müller e Mário Domingues fazem instigantes reflexões associando poesia visual, máquina de escrever e técnicas de montagem.

Carlos Costa analisa o filme Matador, de Pedro Almodóvar, na perspectiva dos estudos da recepção, e convida à polêmica ao nos dizer que a experiência estética é prejudicada pelas armadilhas que o diretor coloca para o espectador.

Os argumentos que contrapõem Margem versus Terra em Transe, ou seja, Ozualdo Candeias e Glauber Rocha, são analisados no artigo de Daniela Pinto Senador, repondo a controvérsia Cinema Marginal/Cinema Novo.

Rio 40 Graus, que completou em setembro cinqüenta anos, e Cidade de Deus, são revisitados sob a ótica das noções de realismo e realidade.

O evento marcante da radiodifusão, a narração de $A$ Guerra dos Mundos, por Orson Welles, em 1938, é o pré-texto para estudar os efeitos de realidade produzidos pela dramatização dos fatos no telejornalismo, no trabalho de Teresa Cristina da Costa Neves.

Alex Ricardo Chagas resenha o livro A Rádio Nacional - alguns dos momentos que contribuíram para o sucesso de Rádio Nacional, organizado por Cláudio Pinheiro. Parte do projeto de reconstrução da Rádio Nacional (um projeto nacionalista?). A resenha é um convite não somente para a leitura, mas também para examinar a excelente programação visual do livro e rever momentos marcantes da história da rádio brasileira. 